\title{
METHOD OF PHYSICAL THERAPY OF PERSONS WHO HAVE SUFFERED A MYOCARDIAL INFARCTION AT THE DISPENSARY-POLYCLINIC STAGE
}

\section{Dmitriieva Nikol ${ }^{1}$}

DOI: https://doi.org/10.30525/978-9934-571-89-3_81

The urgency of the research topic is due to the fact that the diseases of the cardiovascular system occupy the first place in the general list of diseases, which often lead to mortality and disability. The need to use physical therapy in a complex recovery is proved by theory and practice.

Persons who have suffered a myocardial infarction, at the dispensary-polyclinic stage of physical therapy, belong to the category of persons suffering from chronic

\footnotetext{
${ }^{1}$ Akademician Youriy Bugay International Scientific and Technical University, Ukraine
} 
ischemic heart disease with post-infarction cardiosclerosis. The tasks of physical therapy at this stage are: restoration of cardiovascular system function by incorporating mechanisms of cardial and extracardial compensation; increased tolerance to physical activity; secondary prevention of coronary heart disease; restoration of work capacity and return to professional work, preservation of restored ability to work; possibility of partial or complete refusal of medicinal preparations; improving the quality of life of the patient.

To prolonged physical activity of patients who have suffered a myocardial infarction, it is allowed to begin 3-4 months after it. According to functional capabilities, which are determined by veloergomagrya, spiroergometry or clinical data, patients are referred to the I-II (strong group), or to the III (weak group) of the functional classes. If classes (group, individual) are conducted under the supervision of the instructor of kinesiotherapy, the medical staff, they are called controlled or partially controlled, conducted at home at an individual plan.

According to the developed method of physical therapy of persons who have suffered a myocardial infarction at the dispensary-polyclinic stage, the course of long-term controlled training is divided into 2 periods: preparatory, duration 2-2,5 months, and basic, duration 9-10 months. The main period is divided into 3 subperiods. In the preparatory period classes are conducted by group method in the hall 3 times a week for 30-60 minutes. The optimal number of people in the group is 12-15 people. In the process of training methodologist should monitor the state of those who are engaged: on external signs of fatigue, on subjective feelings, heart rate, respiratory frequency and more. With positive responses to these loads, patients are transferred to the main period that lasts 9-10 months. It consists of three stages.

The first phase of the main period lasts 2-2,5 months. The lessons at this stage include:

- exercises in the training regime with the number of repetitions of individual exercises to 6-8 times, performed at an average pace;

- complicated walking (on socks, heels, on the inner and outer sides of the foot for 15-20 seconds);

- dosed walking at an average pace in the introductory and final parts of the classroom; at a fast pace (120 steps per minute), twice in the main part (4 minutes);

- to subsidize running at a rate of 120-130 steps per minute or complicated walking ("skiing step", walking with a high knee lift for 1 minute);

- training on bicycle with a dose load of time (5-10 minutes) and power (75\% of the individual threshold power);

- elements of sports games.

The heart rate during the loads may be $55-60 \%$ of the threshold in the functional group III (weak group) and $65-70 \%$ in the persons of the I-II functional classes (the "strong group"). In this case, the peak of the heart rate can reach 135 beats per minute, with fluctuations from 120 to 155 beats per minute.

During exercise, the frequency of cardiac contractions such as "plateau" can reach 100105 beats per minute in the weak and 105-110 beats per minute in strong groups. The duration of the load on this pulse is 7-10 minutes. 
At the second stage (duration of 5 months) the training program is complicated, complexity and duration of loads increase. The dosage run is used in slow and average pace (up to 3 minutes), work on bicycle ergometer (up to 10 minutes) with a capacity up to $90 \%$ of the individual threshold level, playing volleyball through the grid (8-12 minutes) with a ban on jumps and a one-minute rest through Every 4 minutes. The heart rate during loads of the plateau type reaches $75 \%$ of the threshold in the weak group and $85 \%$ in the strong. The peak in the heart rate reaches 130-140 beats / min. The role of therapeutic exercises diminishes and the value of cyclic exercises and games increases.

At the third stage, which lasts for 3 months, the intensification of loads is not so much due to an increase in "peak" loads, but due to prolongation of the physical activity of the plateau type (up to 15-20 minutes). The heart rate at the peak of the load reaches 135 beats per minute in the weak and 145 in the strong groups; pulse growth at the same time is more than $90 \%$ in relation to the heart rate of rest and $95-100 \%$ in relation to the threshold heart rate.

\section{References:}

1. Mukhin V. M. (2000). Fizychna reabilitatsiia : pidruchnyk dlia studentiv vyshchykh navchalnykh zakladiv fizychnoho vykhovannia i sportu [Physical rehabilitation: a textbook for students of higher education institutions of physical education and sports]. Kyiv: Olimpiiska literature. (in Ukrainian)

2. Popov S. N. (2005). Fyzycheskaia reabylytatsyia: uchebnyk dlia studentov vysshykh uchebnykh zavedenyi, obuchaiushchykhsia po Hosudarstvennomu obrazovatelnomu standartu 022500 "Fyzycheskaia kultura dlia lyts s otklonenyiamy v sostoianyy zdorovia" (Adaptyvnaia fyzycheskaia kultura) [Physical rehabilitation: a textbook for university students enrolled in the State educational standard 022500 "Physical culture for persons with disabilities in the state of health" (Adaptive physical culture)]. Rostov na Donu: Fenyks. (in Russian) 